\title{
Security Challenges and Leadership in Africa, 1960-2019
}

\author{
James C. Chukwu \& Chinelo Chizoba Anachunam \\ http://dx.doi./org/10.4314/ujah.v20i3.15
}

\section{Abstract}

There is need to develop a new approach towards understanding behind the prevailing level of insecurity in Africa. The continent is in the grip of various destructive forces that are coalescing to give it a failed - status toga. The current state of insecurity in most African countries is a manifestation of deep-rooted and structurally entrenched crisis of development that creates the environment for the emergence of conditions of poverty, unemployment, and inequality in those countries. These in turn, lead to frustration, alienation and, ultimately, social discontent that spark violence and insecurity. Without the enabling environment, these conditions could not have metamorphosed into serious national security problem threatening to tear the countries apart. Although Africa may appear to be failing, the trends leading to this situation are reversible, if seriously proactive and sustained measures could be adopted by African leaders. Policymakers have the duty to arrest this drift through social justice and development. It is on this backdrop that this paper examines this core issues on security challenges and leadership in Africa. The work also highlighted the linkage between development and security in Africa. The work also adopted secondary sources of data such as books, journal articles, newspapers and internet sources. Also used was the historical approach in its analysis. Reports obtained from these sources formed the bulk of this Research's tool of assessment. 
Chukwu \& Anachunam: Security Challenges and Leadership in Africa, 19602019

Keywords: Security, Challenges, Leadership, Development, Africa

\section{Introduction}

Despite over fifty years of political independence, Africa's aspiration and hopes remain today largely unfulfilled. The security challenge and leadership question has become a recurring issue in the discourse on the African project. Seteolu (2004:70) pointed out that the governing class has been target of pillory, vilification, condemnation and disdain in view of the pervasive and persistent socioeconomic and political crisis. He stated further that the economic domain has been characterized by huge external debt overhang, net capital flight, disinvestments, collapse of social infrastructure, food crisis and insecurity, over-devalued national currency, pervasive poverty, unpopular, repressive and alienating economic policies. It was recognized that Africa's failures have come about largely as a result of among other things; progressive distancing of African from the masses of the people; inadequate preparation of the leadership that assumed the responsibility to govern their countries.

The governance institutions and practices that were bequeathed to a majority of African states at independence were, for the most part, ill-adapted to the African realities and the continent's development challenges (Afegbua, 2012). Every society across the globe has its peculiar problems and challenges (Chukwu. 2019: 3). Therefore, one of the major challenges that have faced African states since the advent of political independence has been that of establishing and sustaining appropriate governance institutions and practices that would engender democratic practices and promote sustainable development on the continent. In consequence, African 
governments, both individually and collectively, have over the years, evolved various strategies and responses to the ever-present challenge of governance.

Given continued conflict in the Democratic Republic of the Congo (DRC), where about 5.4 million civilians have been killed in brutal civil wars since 1990 and the intensified mayhem in the Sudan, where more than 300,000 Arabs and Africans have been slaughtered in Darfur and elsewhere since 2003 (Afegbua, 2012) ensure lack of clear ideology that is compatible with the history, culture and the realities at the ground. Since the conception of its independence, south Sudan has entered in to a social and political instability that calls for the international community. Moreover, the continued tension between the north and south in Côte d'Ivoire; battles in the Niger Delta, where oil wealth exists amid extreme deprivation; a war in northern Uganda and piracy at sea and bitter struggles on land in Somalia, the unconstitutional removal of a legitimate leader in Egypt in 2014, and its increased openness and the consequent vulnerability to external forces, the long lasting hydro politics between Ethiopia, Egypt and other riparian states, the challenging issue of terrorism in the horn of Africa, no governance, or prolonged bad governance, might seem more the sub-Saharan African trend than good governance(Ibid).

Enhancing good governance is a considerable challenge for the African region. Despite good progress in recent years, there is still much work to be done to address bad practice including corruption and political interference in decision making. A key aim of the New Partnership for Africa's Development (NEPAD) is improving corporate governance. It believes that without it, new programs and projects to promote Africa's development will not be delivered (New Partnership for Africa's Development, (http://www.nepad.org.)). 
Chukwu \& Anachunam: Security Challenges and Leadership in Africa, 19602019

Good governance is a critical element required for effective and sustained peace and security, economic growth and human development. As African States make strenuous efforts to meet the developmental goals enshrined in the internationally-agreed Millennium Development Goals (MDGs), it is becoming increasingly apparent that without improved governance such goals cannot be attained. Managing climate change is also a governance issue. Africa is now facing a significant undertaking on climate-change adaptation amidst great adversity, instability and economic challenges (Afegbua, 2012). Governments are tasked with the responsibility of designing and implementing effective policies of mitigation and adaptation to climate change. This requires organizational and institutional capacities as well as coherent actions built on accountable, transparent and participatory systems of governance.

It is instructive to note that no nation has achieved meaningful development socially, politically or economically without the input of or effective leadership (Obasola, 2002:10). Thus, in contemporary discourse, the concept of leadership and governance has attracted a wider spread interest as they serves as the pivot on which social, political and economic structures rest. The numerous problems which have been bedeviling African states vis-à-vis ethnic and communal clashes, increasing crime wave, drug trafficking, advanced fee fraud etc. have been blamed on ineffective leadership. While it is true that there have been apparent leadership and governance crises in Africa, the last two decades has witnessed struggle to engender effective leadership and governance in Africa.

This paper integrates the concepts of leadership, development and security and shows that in the ultimate, level of national development determines the level of security of a country 
at any particular time. To illustrate this, the paper proceeds from the view that there is a connection between the concept of national development and national security in which this critical development indicator: leadership challenges in Africa continent determine its internal security condition. The paper starts with a review of the conceptual clarification of leadership, development and security where it establishes the nexus between them and proceeds with an analysis of the important variable of insecurity in Africa, namely, leadership challenges in Africa, Then conclusion and recommendations.

\section{Conceptual Clarification}

\section{Leadership}

The problem in an intellectual discourse of this nature is usually concerned with the definition of terms. It is really very difficult to attempt a definition of leadership, or in other words it is difficult to define what makes certain persons to be leaders. For example, some researchers define leadership in terms of personality and physical traits, while others believe leadership is represented by a set of prescribed behaviours.

Udegbe (1999:282) opined that, Leadership is the process of creating the subordinates' identification with the group's mission and creating their desires to achieve the group's goal . According to Graig (2005), leadership is defined as a social influence process in which the leader seeks the voluntary participation of subordinates in an effort to reach organizational goals. While Robert affirms that leadership involves a complex interaction among the leader, the followers, and the situation.

Hackman (2006) classified these conceptions into four primary definitional themes; these are; 
Chukwu \& Anachunam: Security Challenges and Leadership in Africa, 19602019

(a) Leadership is about what you are: this definitional theme focuses on leader traits and attributes and is one of the oldest ways of conceptualizing leadership. This emphasis is on identifying the characteristics that define natural or born leaders.

(b) Leadership is about how you act: From this perspective leadership is defined as the exercise of influence or power. To identify leaders, we need to determine who is influencing whom. For instance Hersey (1984:14) defines leadership as "any attempt to influence the behaviour of another individual or group".

(c) Leadership is about what you do: This definitional thread focuses on the role that leaders play.

(d) Leadership is about how you work with others: This definitional theme emphasizes collaboration. Leaders and followers establish mutual purposes and work together as partners to reach their goals (Poulin, et al 2007:302).

In the views of Aguda (1995:26), a person may attain the position of leadership in one of several ways. The first method is self-imposition, which is totally devoid of constitutionality. Secondly, a group of persons may forcefully impose a leader on the generality of people. Nigeria, for instance have of course become aware of this since 1966. A person may come to the position of leadership through a demonstration of leadership qualities over a long period of time. Examples of such are Nelson Mandela of South Africa, Kwame Nkrumah of Ghana, Robert Mugabe of Zimbabwe, Sertse Khama of Botswana, Kamuzu Banda of Malawi, Jomo Kenyatta of Kenya, and Julius Nyerere of Tanzania. 


\section{Development}

Development is a relative and mostly contested concept (Hettne, 2010). Nevertheless, it is possible to arrive at some specific indicators of development that are widely acceptable. For instance, it is easy to argue that every human society aspires to strong, efficient and dynamic economic and political institutions that anticipate the yearnings of their people and respond to them accordingly and promptly. It is also possible to argue that in every society there are minimum expectations which all members share. These include access to functional health facilities, access to safe drinking water, universal qualitative education, and equal opportunity for all members in public affairs where competition based on merit is upheld over and above other considerations. All these are universal values that transcend cultural and political boundaries. Thus, if there is anything actually relative about our conception of development that may largely be because of perspectives from which one chooses to understand it. This is why students so often try to isolate the elements of national development and talk of them as individual topics. Thus, one hears about cultural, social, economic, political, and even religious development as if it is possible to provide a proper analysis of development without integrating these and considering development from a holistic perspective. For instance, Gopinath (2008:91)argues that development can only be measured in monetary terms, and consequently, a developing country is one in which "there is a significant potential to raise the per capita standard of living" of its people. This, no doubt, is the hangover from the intellectual segregation that dominates developmental literature in the 1960s and 1970s when most models of development drew their theoretical sustenance from classical economics. In that conception, economic growth was equated with 
Chukwu \& Anachunam: Security Challenges and Leadership in Africa, 19602019

development and was generally considered as the fundamental objective of the decolonized states of Asia and Africa (Peshkin \& Cohen, 1967:11; Salmen, 1991:295).

Even in these isolationist conceptions, it is possible to discern an overriding understanding in which the notion of a qualitative transformation occurs in space and time through the trickle-down effect. Therefore, development is no more than a description of a particular state or physical condition in which there is a corresponding progress in both the physical growth and maturity of a particular object. Applied to human societies, development simply refers to a state, condition or stage, which entails positive transformation in both quantity and quality of life for all members of a particular society. Where there is corresponding decline or retrogression in the quality of life for a significant portion of the population, we describe that as the state of under-development (Rodney, 1972). In effect, development and underdevelopment connotes a relational state in which one mirrors the exact absence of the other.

Mirakhor and Askari (2010:1) write that development means "quantitative growth, qualitative improvement, and expansion in the capabilities, capacities, and choices of individuals, groups or states". Similarly, Tisdell (1988) writes that development is "the modification of the biosphere and the application of human, financial, living and non-living resources to satisfy human needs and improve the quality of life". A distinct thread that permeates these conceptions of development concerns the recognition that improvement on the quality of life of all members of human society is the fundamental objective as well as the primary goal of development. The point here is the emphasis on empowerment and skill building among members of the society to be able to transform their living conditions. The best, succinct, 
and analytical conception on development remains that given by Dudley Seers who raises fundamental socio-economic and political questions in his definition and seeks to relate them to human development. According to Seers (1972:124):

The questions to ask about a country's development are... What has been happening to poverty? What has been happening to unemployment? What has been happening to inequality? If all three of these have declined from higher levels, then beyond doubt this has been a period of development for the country concerned. If one or two of these problems have been growing worse, especially if all three have, it would be strange to call the result 'development', even, if per capita income doubled.

The emphasis, thus, is on the individual as the integral member of the community; the object of any transformation, not on economic growth based on abstract statistics. It is the position of this paper that this conception of development provides an excellent analytical framework from which a proper explanation on the relationship between development and security can be carried. Instructively, the three indicators, as provided by Seers, form the basis upon which this paper proceeds with its analysis.

\section{Security}

What constitutes security in modern times is a question that has never been answered satisfactorily by scholars. Its perception even within one community varies in time (Ejogba, 2006:305). For instance, until recently, most of the mainstream writings on security studies literally defined it in terms of a state's capabilities to defend its territorial integrity from threats, actual and imagined, as well as acts of aggression from other potential enemies (Okwori, 
Chukwu \& Anachunam: Security Challenges and Leadership in Africa, 19602019

1995:20). To this end, states build and equip armed forces towards achieving this goal. The main assumption of this conception is that threat of violence, and the actual ability to commit violence by a state, against an enemy successfully deters threats and aggression (Rouke, 2005:308; Alabi, 1997:129). At the domestic level, the belief is that internal law-enforcement agencies and other instruments of domestic intelligence are all that is required for a state to be secured.

There is however, an evident shift on what actually constitutes security in the post-Cold War era. Presently, there is an attempt to broaden it to accommodate other relevant, if not critical, elements within this conception. Issues such as economic development, equality, political accountability and goodgovernance are now regarded as fundamental to any comprehensive understanding and explanation on the question of security. Perhaps, this is because of the fact that the conventional militaristic conception of security that dominated the Cold War discourse proved ineffectual and grossly incapable of meeting security expectations among many countries. In this new conception, human development is considered as central (Hettne, 2010; Booth, 2007). Thus, we see in this shift, a new and broader conception in which security entails the capacity of a state to defend itself from external threats with all the necessary means at its disposal, and internal threats through overall socio-economic well-being of its citizenry (Absolute Astronomy, 2011; Tedheke, 1998:6). Here, there is a greater recognition of the relevance of other elements such as political, environmental, economic, and social factors as irreducible components of security of any country(Buzan\& Hansen, 2009).Hettne (2010) defines security "as a reasonable level of predictability at different levels of the social system, from local communities to the global level...".The 
understanding here is that at the global level, there is a presence of an order which is predicated upon the predictability of the behaviour of other members within the system. At local level, security thus includes the ability of the state to predict the likely implication of any particular condition on its citizens. The recognition lies squarely not on the state's ability to enforce law and order, though that may be important, but in creating the necessary socio-economic conditions that guarantees fair amount of predictability on the behaviour of its citizens. For our purpose, we define security as a state of reduced or contained threats and tension in which the stability of a state is not in an imminent danger of disruption from within and without. Stability is here viewed as the order, regularity and pattern, which characterized the state's condition over an extended period.

\section{Linkage between Development and Security in Africa}

The linkage between development and security usually takes one of the following two forms. It can be preventive. Alternatively, it can be promotional (Hettne, 2010). Preventive linkage means prevention of the causes that generate conflict in any particular human society, while promotional linkage or what Hettne (2010) calls "prevention" refers to creating the conditions that generate peace in the society by addressing the structural imbalances in the socio-economic conditions of the people, which traditionally are the sources of conflict. In this case, the emphasis will be in identifying and removing the root causes of conflicts in the society such as inequality and mass poverty. In trying to establish a clear nexus between development and security, we need to remember the impossibility of establishing peace and order in any society in which there exists fundamental contradictions in its economic structure. It is these contradictions, more often, in the third world 
that provides the manure that nurture and sustain feelings of alienation, marginalization, frustration and resentment among the poor class of the society, and which ultimately translate into anger, radicalization and violence (Oyeshola, 2005:123). In those economies, especially African, where a wide cleavage exists between wealth and income distribution, and in which as a result, poverty and unemployment complement one another on the largest possible scale, there is an evident propensity for the people, especially youth to resort to means, other than lawful and socially accepted, in satisfying their basic needs. Thus, we see parallel to the decline in productivity and equitable income distribution, a corresponding increase in urban crimes such as armed robbery, prostitution, drug peddling, touting, kidnappings, and cultism in institutions of higher learning.

For those countries, in Africa, like Nigeria, where economic crisis is more acute, and the state risks failure of its institutions of governance, urban crime usually takes secondary stage in relation to the emergence of other violent anti-state groups that seek to supplant the state in obtaining loyalty from the people. The ensuing competition, often violent and bloody, provides the most ample evidence of how (under)development and (in) security always complement each other in all human societies. (Tedheke, 1998:67) provides an excellent analysis of how development is essentially synonymous with security because "any country that seeks to achieve adequate military security against the background of acute food shortages, population explosion, low level of productivity, fragile infrastructural base for technological development, inadequate and inefficient public utilities and chronic problem of unemployment has false sense of security". Accordingly, any measure conceived by a state towards addressing the problem of insecurity must start with recognizing that "peace 
and order are sine-quo-non for the development of any society" (Ode, 2003:136).

\section{Leadership Challenges in Africa}

Suffix it to say at this juncture that it is sad to observe that Africa's leadership selection process takes the imposition pattern directly or indirectly. Worrisome too is the fact that the Africa's political formation is along tribal groupings and ethnic aggregations thus visionary leaders are dropped while mediocre are often selected or imposed on the masses. In view of the above, therefore, the following suggestions are proffered to help to ameliorate the seemingly endemic leadership problems in the continent so as to achieve a measure of credibility and purposeful leadership.

The immediate task of leadership in Africa is to restore hope. To pull our people out of the pit in which they have found themselves, to rescue the people from the ravages of military dictatorship and from the ruling clique, protect unconstitutional removal of leaders from their legitimate position, etc. The challenges for leadership in Africa are enormous, serious urgent and important. A leader of Africa has work to do. He will need vision, organizing ability, wisdom, administrative skills and more. The search for leadership in Africa is a search for social justice, which automatically, eliminates social injustice. The principle of justice is to give each person or group what is his/her due and to demand the contribution of each on the basis of equal consideration.

Africans should learn to deal sincerely and honestly with one another so that the question of mistrust and suspicion amongst the various ethnic groups in the continent would be wiped away. It is only then that any qualified African can be elected into 
Chukwu \& Anachunam: Security Challenges and Leadership in Africa, 19602019

leadership positions without mistrust, suspicion, acrimony or reference to his/her ethnic or religious background.

The leadership search as opined by Seteolu (2004:74) should interrogate the option of independent candidacy a basis to attract professionalism, intellectual, business and industrial elite to contest political office without partisan platform. This option will likely enhance the quality of politicking, promote issue-based politics and recruit new entrants into the political class with somewhat personal integrity and pedigree, and reduce the cost of political power. The independent candidate as a political type will more likely suit the local levels of governance where community attachment, honour and integrity as opposed to party influence or domination are the determinants of political choice.

The challenges for Africa and its leadership endowed with courage, determination, tolerant and honesty and the creation and promoting the process of endowing political institutions with necessary legitimacy which is their ultimate safeguard against violent overthrow (Kamuntu, 1993). Africa cannot afford to continue with ill-prepared and unassisted leaders. Those on whom the burden of leadership will fall in future must fully comprehend their responsibilities, duties, and obligations. They must be exposed and there must be a carefully planned preparation for leadership if they are to meet the challenges that will face them especially the security challenge.

As recommended by African Leadership Forum (1993), that one solution is to hold periodically the "African Leadership Forum" - a series which may be national, sub-regional, regional, and international in dimension and may vary in duration. The purpose is to acknowledge the awareness of young, potential African leaders, playing special emphasis on diagnosing apparent failures of the past; as well as an understanding of multiple 
dimensions and complex interrelations of local, national, regional and global problems; and seeking possible approaches at proffering solutions to them.

The problem which troubles Africans most is the failure of political leadership. There are of course failures in other domains, but these are traceable in the consciousness to political leadership deficiencies. Seteolu (2004:74) summarizes the challenge from Nigerian perspective thus;

The political elite are not a productive class, but rely on the control of state structures to access economic rewards. The over politicization of the Nigerian state is also understood in the context of the unmediated struggle for power, influence and patronage. The nature of political contest ensured the emergence of a local governing class without ideological commitment. Rather than pursue political contests within ideological frameworks, politics became a contested terrain for shallow, self-centered political gains.

The de-ideologisation of African politics means that aspirant political leaders do not see a pressing need to state their macro-vision for the continent. There is no explicit formulation of any systems values. The nature of Nigerian state evolved a predatory political class that was concerned with power struggle, consolidation, alignment and realignment in the context of hegemonic control... This is linked to the lack of ideology in the political space, monetization of the political process, expand the basis of political participation and canvass alternative policy agenda Seteolu (Seteolu, 2004; Obi, 2000). Ake and Onoge (1995:53) also pointed out that;

Political leadership is parochial rather than national; and corruptly converts national resources into its project 
of primitive accumulation. Ethnic diversity is manipulated to stay afloat to the detriment of national cohesion. There is an embarrassing lack of national heroes. The failure was usually explained either by the easy manipulability of the cultural pluralist background, or by the "two publics" antagonism.

The personalized nature of rule in so many African countries means not only that public policy making lacks the logic and empirical content that typically characterizes such an activity in order contexts but also that governance structures are largely informal and subject to arbitrary change (Hyden,1992:23). Following the widespread abuses of civil and political rights by such rulers as Idi Amin, Emperor Bokassa, and Macias Nguema in the late $1970^{\text {ee }}$, however, Africans gradually began to recognize their significance. One of the most important messages coming out in literatures is that African government can no longer at will, by invoking the demand for national unity; violate civil and political rights of their citizens. Also equally relevant and important is the absence of political will. A political will is the compelling force for sound leadership quality, the ability to do what is right, what is relevant and what is attainable within the context of patriotic nationalism. Political will very often means personal or group sacrifices. It implies the ability to implement policies that have a nationalistic important and relevant without allowing pockets of interest to detract from what should naturally be of national benefit. Most African leaders assumed their role with limited experience and training in the art and science of directing and effectively managing the affairs of a modern state (Kamuntu, 1993). The challenge to African leaders is thus to develop the capacity that would enable us to strike a balance between the 
values of African societies and the governance that our nations must follow. However, the concern must be to blend the two rather than to treat them as if they were mutually exclusive. Yimer (2015) postulated that the political power in Africa became concentrated in one political party and finally in hand of one leader. Making the rise of the supremacy of the office of the President over all organs of government, most African Presidents enjoyed re-election in perpetuity without any competition. Kamuntu (1993) observes further that consequent resistant to the concentration of power to the hands of one man - the President was brutally suppressed with greater violations of human rights, resulting in massacres and millions of Africans becoming refugees or becoming displaced persons and many qualified African's seeking employment opportunities in foreign countries in search of personal security ${ }^{46}$. Africa's continuing crisis presents a tremendous challenge to the continent and its leadership. Therefore, based on the above analysis, we can possibly assume that the trouble with Africa is simply and squarely a failure of leadership. There is nothing basically wrong with the African character or political system in operation. The character of political leadership became a problem as most of them lost or lacked control of effective leadership. This led to the scramble and partition of state resources to suit their purpose.

\section{Conclusion}

In the final analysis, the paper argue that so long as we continue to treat the issue of national security separately from the issue of national development in which challenges of poverty, inequality, unemployment, social exclusion on account of tribe and religion are not tackled proactively, the problem of insecurity will remain very much alive and will continue to plague the country. This 
applies to other developing countries, especially in Africa, that are grappling with the challenges of economic growth and development, political reforms and democratization. This framework, though designed with Africa in view, recognized the similarity of the challenges which most African countries face today. Wide and institutionalized poverty, social inequality and injustice, stagnant economic growth and development, half-hearted political reforms, shabby democratization processes, corrupt and despotic leadership have remain some of the glaring landmarks for most African countries. As a result, youth restiveness and violence, social instability, and conflicts have continued to plague them.

\section{Recommendations}

Following this discourse, we can at least propose the following important recommendations.

First, for developing countries like, national security is synonymous with national development, and treating them as separate subjects is not only counter-productive, but is fraught with danger. As such, policymakers need to appreciate this important fact, and start taking the necessary steps and building the institutions that could truly ensures justice, accountability and development in their countries. Otherwise, all measures designed to address insecurity will remain futile.

Second, the international community cannot afford to remain impervious to issues related to social justice, political reforms, democracy and good governance in the developing countries. These remain central to peace, progress and sustainable development, and by extension, global peace. The involvement of the developed world in all spheres that promote these themes in the developing world is very important. Situations where world powers, for strategic reasons, blind themselves to gross human 
rights violations, bad governance, corruption, social injustice and inequality among their third world allies do no one any good. For in the end, it nourishes the conditions that endanger the global peace.

Therefore, helping developing states in Africa by insisting on good practice by its leaders through good governance, genuine democratization process, and accountable political leadership, is a collective international obligation.

\section{James C. Chukwu}

Department of History \& international studies

Nnamdi Azikiwe University, Awka

jimco4real@gmail.com

\&

\section{Chinelo Chizoba Anachunam}

Department of Igbo, African \& Asian Studies

Nnamdi Azikiwe University, Awka

mbaekwechinelo@gmail.com

\section{References}

Absolute Astronomy (2011). National security. Retrieved 17 October 2011 from:

http://www.absoluteastronomy.com/topics/National_security Adelman

Afegbua, S (2012), The Challenges of Leadership and Governance in Africa: International Journal of Academic Research in Business and Social Sciences September 2012, Vol.2, No.9 ISSN: 22226990.website: www.hrmars.com/journals.

Aguda, A. (1995). "Nigeria: In Search for Leadership", Keynote Address delivered at the Third Obafemi Awolowo Foundation Dialogue. 
Chukwu \& Anachunam: Security Challenges and Leadership in Africa, 19602019

Ake, C and Onoge, O (1995). "The Theories and Conception of Leadership", in Fafowora, et al (eds), Nigeria: In Search of Leadership, Ibadan: Spectrum Book.

Alabi, D. O. (1997). Issues and problems in the Nigerian defence policy in the 1990s: A critical review. Nigerian Army Journal, 9(3), 128-143.

Booth, K. (2007). Theory of world security. Cambridge: Cambridge University Press.

Buzan, B. \& Hansen, L. (2009). The evolution of international security studies. Cambridge: Cambridge University Press.

Chukwu, C. J. (2019). "Boko Haram Insurgency and its Implications on National Integration in Nigeria", International Journal of Arts and Social Science Research, 1(2) 2019, 13. retrieved from

http://www.theinterscholar.org/journals/index.php/isjassr/artic le/view/10

Ejogba, O. A. (2006). African security in the twenty-first century. Nigerian Forum: A Journal of Opinion on World Affairs, Nigerian Institute of International Affairs, 27, (910), 303-319.

Gopinath, C. (2008). Globalization: A multidimensional system. Los Angeles: Sage.

Graig, E.J (2005). Meeting the Ethical Challenges of Leadership, New Delhi: Sage Publications.

Hackman, M (2006). "The Challenges of Defining Leadership: The Good, the Bad, and the Ugly", A paper presented at International Leadership Association Conference, November, Chicago, 11.

Hersey, P (1984). The Situational Leader, Escondibo, CA: Center for Leadership Studies.

Hettne, B. (2010). Development and security: Origins and future. Security Dialogue, 41(1), 31-52. Obasola, K.E (2002). "Leadership in Religious Organizations and Societies: 
Traditional Yoruba Perspective", in CASTALIA, Vol 12, No 2, Dec.

Hyden, G (1992). "Governance and the study of Politics", in Hyden, $\mathrm{G}$ and Bratton, M (eds), Governance and Politics in Africa, Boulder \& London: Lynne Rienner Publishers.

Kamuntu, E.R (1993). Leadership Challenges in Consolidating Democracy and Good Governance in Africa, A paper presented at conference of The Leadership Forum, Nairobi, Kenya: March 10-12.

Mirakhor, A. \& Askari, H. (2010). Islam and the path to human and economic development. New York: Palgrave Macmillan.

Obi, C. (2000). "Last Card: Can Nigeria Survive Another Transition", African Journal of Political Science, Vol 5, No 2.

Ode, I. O. (2003). An assessment of the activities of vigilante group in Nigeria: The case of Makurdi Town of Benue State. (in). Jike, V. I. (ed.). (2003). The Nigeria Police and the crisis of law and order: a book of readings. Lagos: NISS.

Okwori, A. S. (1995). Security and deterrence: Towards alternative deterrence strategy For Nigeria in the 21st century and beyond. Defence Studies: Journal of the Nigerian Defence Academy, Kaduna, 5, 19-28.

Oyeshola, D. (2005). Conflict and context of conflict resolution. IleIfe: OAU Press. Peshkin, A. \& Cohen, R. (1967). The values of modernization. The Journal of Developing Areas, 2(1), 722.

Peshkin, A. \& Cohen, R. (1967). The values of modernization. The Journal of Developing Areas, 2(1), 7-22.

Poulin B.J. et al (2007). "Leadership and Succession: The Challenge to succeed and the Vortex of Failure" in Leadership, Vol 3, No 3, London and New Delhi; Sage New Delhi: Sage Publication Publications. 
Chukwu \& Anachunam: Security Challenges and Leadership in Africa, 19602019

Rodney, W. (1972). How Europe underdeveloped Africa. London: Bugle L-Ouverture.

Rourke, J. T. (2005). International politics on the world stage (10th ed.). New York: MacGraw Hill.

Salmen, L. (1991). Reducing poverty. Public administration and development, 11( 3), 295-302.

Seers, D. (1972). The meaning of development. (in) Uphoff, N. T. \& Ilchman, W. F. (eds.). (1972). The political economy of development: Theoretical and empirical contributions. Berkeley: University of California.

Seteolu, D (2004). "The Challenge of Leadership and Governance in Nigeria", in Odion Akhaine, S (eds),Governance: Nigeria and the World, (Lagos: CENCOD. 2004), 70.

Tedheke, M. E. U. (1998). Defence and security in Nigeria: Beyond the rhetorics. Defence Studies: Journal of the Nigerian Defence Academy, Kaduna, 8, 1-22.

Tisdell, C. (1988). Sustainable development: Differing perspectives of ecologists and economists, and relevance to LDCs. World Development, 16(3), 373-384.

Udegbe, I.B (1999) "Leadership: Nature and Pathways to Effectiveness", in Udegbe, I.B, et al (eds), Psychology: Perspectives in Human Behaviour, A Publication of Dept. of Psychology, University of Ibadan.

Yimer, M Governance and Leadership Challengies in Africa: International Journal of Political Science and Development March 2015, 3(3) retrieved from http://www.academicreseachjournals.org/IJPSD/index.html 